\title{
Implementation of lean practices facilitated by BIM functionalities in the construction phase: advances and opportunities
}

\author{
Implementação de práticas lean facilitadas por \\ funcionalidades BIM na fase de construção: avanços e \\ oportunidades
}

\section{Renato Nunes Mariz \\ Flavio Augusto Picchi}

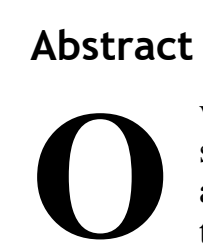

ver the past few decades, construction productivity has been at a standstill. Lean and Building Information Modelling (BIM) is attracting increasing interest in the construction industry as a way to increase construction productivity. This paper aims to contribute to the body of knowledge by identifying hitherto unexplored opportunities for the use of BIM functionalities as a support and as facilitators of the application of lean practices in the construction phase. A systematic literature review was adopted as the methodological approach in this research, and reported case studies related to the scope of this paper were searched. The results show that lean practices can be classified into four degrees of BIM support based on the level of current exploration. Just one lean practice (the last planner system) has been extensively explored, three have been reasonably explored, and five have just been preliminarily explored. Five practices have not been explored at all. This research summarises the already studied and the potential additional uses of BIM functionalities to support each lean practice, showing that lean practices supported by BIM functionalities are still underused and that further studies can explore additional ways to support these practices. This study holds great value for a broader practical application of lean practices, bringing faster and easier results with more extensive BIM support.

Keywords: Building information modeling. Lean construction. Lean practices.

\section{Resumo}

A produtividade na construção civil está estagnada ao longo das últimas décadas. O interesse nas abordagens Lean and BIM tem crescido nos últimos anos, como forma de aumentar a produtividade na construção. O objetivo desta pesquisa é identificar oportunidades ainda não exploradas do uso de funcionalidades BIM como suporte e facilitadoras da aplicação de práticas lean. Foi utilizada a revisão sistemática de literatura como método da pesquisa. Os resultados do cruzamento das práticas lean e funcionalidades BIM indicaram 4 níveis de classificações de aplicações. Somente uma prática foi considerada muito explorada (last planner system), 3 foram consideradas

${ }^{1}$ Renato Nunes Mariz 1 Universidade Estadual de Campinas Campinas - SP - Brasil

${ }^{2}$ Flavio Augusto Picchi 2Universidade Estadual de Campinas Campinas - SP - Brasil

Recebido em 22/06/20 Aceito em 05/04/21 razoavelmente exploradas e 5 pouco exploradas. 5 práticas foram

classificadas como não exploradas. $O$ trabalho conclui sumarizando os usos de funcionalidades BIM já explorados e os potenciais, para cada prática lean. As aplicações de funcionalidades BIM para apoiar práticas lean estão subutilizadas, o que indica que estudos adicionais podem ser feitos para apoiar mais algumas práticas. Isso pode ser de grande valor para uma aplicação mais ampla das práticas lean, trazendo resultados mais rápidos e fáceis, com suporte BIM mais amplo.

Palavras-chave: Building information modeling; Lean construction; Práticas lean. 


\section{Introduction}

Construction productivity has remained practically stable over the past few years, while productivity in other industries has more than doubled (TEICHOLZ, 2013). If construction productivity were to catch up with the total economy, the industry's value added could rise by $\$ 1.6$ trillion a year ( $\%$ of global GDP) (MCKINSEY, 2017). This scenario motivates the use of several approaches that aim to improve sector productivity, including lean and BIM (building information modelling).

Lean thinking emerged in the automotive industry and has proven to have a positive effect on improving productivity by focusing on the elimination of waste and the provision of value to end customer. Its application has spread to different sectors, including construction, with decades of studies and cases (KOSKELA, 2000).

As a digital shared knowledge resource, BIM has changed the way information flows among construction agents, having a significant impact on productivity improvement (POIRER; STAUB-FRENCH; FORGUES, 2015; LIN et al., 2017).

Both approaches, lean and BIM, are attracting increasing interest in the construction industry. Their development in the sector has followed specific and independent pathways, with scarce connections in the early stages. As these concepts have become more adopted, the possible synergies between these approaches have started to be explored, and the use of BIM as a lean implementation facilitator has attracted interest.

Some authors discuss the combination of these two approaches, such as the seminal discussion about the synergies between them presented by Sacks et al. (2010). These authors analyse the relationship between BIM and lean principles, providing an important conceptual and theoretical framework for this analysis. One can identify as a knowledge gap the lack of a more detailed analysis of the synergies between lean and BIM, where lean principles are deployed in lean practices, which could facilitate even more practical applications.

For sustainable lean implementations, people must understand lean principles and select the best way to use the lean practices that are needed in their environment and for their business needs (PICCHI; GRANJA, 2004). Lean practices (concepts and tools, such as Kanban and standardised work) are used to implement lean principles, translating lean principles into routines for the job site. Facilitating such practices through BIM will provide important support for the dissemination of lean.

If we consider the project phase on which studies have focused, another knowledge gap in this discussion can be identified. Santos, Costa and Grilo (2017) pointed out that studies on BIM and construction management have increased over the years but are still scarce compared to studies on other areas, such as design. Lean, on the other hand, presents more applications in the construction phase than in other phases (PICCHI; GRANJA, 2004).

This paper aims to contribute to the body of knowledge by identifying hitherto unexplored opportunities for the use of BIM functionalities as a support and as facilitators of the application of lean practices in the construction phase.

Other authors have discussed the synergies between lean and BIM, but this study focuses specifically on the construction phase and offers a new view, considering lean practices deployed based on lean principles. This approach aims to identify gaps in the use of BIM to facilitate specific and fundamental lean practices, seeking to make contributions with a closer connection to practical applications.

To achieve the stated aim, fundamental lean practices and BIM functionalities were characterised based on the literature. Then, a systematic literature review was performed, in which research on lean and BIM in the construction phase was searched. Finally, a cross-reference analysis was conducted to identify lean practices that have already been supported by BIM functionalities in the literature as well as gaps.

\section{Background: lean practices and bim functionalities}

In this section, we present a summary of the fundamental lean practices and BIM functionalities that will be used for cross-reference analysis.

\section{Lean Practices}

Lean thinking follows some key concepts based on the Toyota production system (TPS). The five lean principles proposed by Womack and Jones (1996) are still a useful reference for understanding the concept: 
value, the value stream, flow, pull and perfection. Some authors, such as Picchi and Granja (2004), Alves et al. (2009), Miranda Filho, Heineck and Costa (2016) and Tezel and Aziz (2017a), have described the main lean practices applied to the construction phase by referring to the lean principles. Based on these studies, Table 1 presents the main lean practices and some practical examples of their use in construction with the respective context. Value to the customer is the first lean principle and is not included in Table 1 since it is considered a driver of all the other principles, as well as the basis of leadership values, mindset development and the waste elimination focus.

\section{BIM functionalities}

$\mathrm{BIM}$ is a methodology for digitally managing design and construction throughout the entire building life cycle (PENTTILÄ, 2006). This methodology has several design and construction functionalities (SACKS et al., 2018). According to Sacks, Radosavljevic and Barak (2010) and Sacks et al. (2018), when applied to the construction phase, the most relevant BIM functionalities are those presented in Table 2, which provides a brief description of each functionality.

Table 1 - Main lean practices and examples of application in construction

\begin{tabular}{|c|c|c|c|}
\hline \multirow{2}{*}{$\begin{array}{c}\text { Lean } \\
\text { principle }\end{array}$} & \multirow{2}{*}{ Lean practice } & \multicolumn{2}{|c|}{ Examples in construction } \\
\hline & & Reference & Context of application \\
\hline $\begin{array}{l}\text { VALUE } \\
\text { STREAM }\end{array}$ & $\begin{array}{l}\text { VSM (value } \\
\text { stream map) }\end{array}$ & $\begin{array}{l}\text { Yu et al. (2009) and } \\
\text { Rosenbaum, Toledo and } \\
\text { González (2014) }\end{array}$ & $\begin{array}{l}\text { Value stream mapping is used to } \\
\text { develop a lean model for house } \\
\text { construction }\end{array}$ \\
\hline \multirow{7}{*}{ FLOW } & $\begin{array}{l}\text { LPS (last } \\
\text { planner } \\
\text { system) } \\
\end{array}$ & $\begin{array}{l}\text { Ballard and Howell (2003) } \\
\text { and Formoso and Moura } \\
(2009)\end{array}$ & $\begin{array}{l}\text { LPS is implemented in different } \\
\text { project types }\end{array}$ \\
\hline & Line of balance & $\begin{array}{l}\text { Arditi, Tokdemir and Suh } \\
(2002) \text { and Kemmer } \text { et al. } \\
(2008)\end{array}$ & $\begin{array}{l}\text { The line of balance is applied in } \\
\text { multistorey buildings }\end{array}$ \\
\hline & Andon & $\begin{array}{l}\text { Kemmer et al. (2006) and } \\
\text { Biotto et al. (2014) }\end{array}$ & $\begin{array}{l}\text { Andon is applied in facility } \\
\text { construction using mobile devices }\end{array}$ \\
\hline & Poka-yoke & $\begin{array}{l}\text { Santos and Powell (1999) } \\
\text { and Tommelein (2008) }\end{array}$ & $\begin{array}{l}\text { Many types of poka-yoke have } \\
\text { been presented as examples in } \\
\text { construction and design }\end{array}$ \\
\hline & Production cell & $\begin{array}{l}\text { Santos, Moser and Tookey } \\
(2002) \text { and Mariz et al. } \\
(2013)\end{array}$ & $\begin{array}{l}\text { Production cells are applied in } \\
\text { drywall and foundation activities }\end{array}$ \\
\hline & $\begin{array}{l}\text { Standardised } \\
\text { work }\end{array}$ & $\begin{array}{l}\text { Mariz et al. (2013), } \\
\text { Fernandes et al. (2013) and } \\
\text { Saggin et al. }(2017)\end{array}$ & $\begin{array}{l}\text { Standardised work is implemented } \\
\text { in foundation and waterproofing } \\
\text { activities }\end{array}$ \\
\hline & Small batch & $\begin{array}{l}\text { Ward and McElwee (2007) } \\
\text { and Bulhões, Picchi and } \\
\text { Granja (2005) }\end{array}$ & $\begin{array}{l}\text { Small batches are applied in } \\
\text { nonrepetitive projects }\end{array}$ \\
\hline \multirow{3}{*}{ PULL } & Kanban & $\begin{array}{l}\text { Arbulu, Ballard and Harper } \\
(2003) \text { and Khalfan et al. } \\
(2008)\end{array}$ & $\begin{array}{l}\text { The adoption of Kanban integrates } \\
\text { an external supplier }\end{array}$ \\
\hline & Heijunka & $\begin{array}{l}\text { Carneiro et al. (2009) and } \\
\text { Barbosa et al. (2013) }\end{array}$ & $\begin{array}{l}\text { A Heijunka box is applied to level } \\
\text { mortar production in the job site }\end{array}$ \\
\hline & Takt time & $\begin{array}{l}\text { Bulhões, Picchi and Granja } \\
(2005) \text { and Mariz et al. } \\
(2012)\end{array}$ & $\begin{array}{l}\text { Takt time is adopted for ceramic } \\
\text { tiling }\end{array}$ \\
\hline \multirow{3}{*}{$\begin{array}{l}\text { PERFEC- } \\
\text { TION }\end{array}$} & $\begin{array}{l}\text { Daily } \\
\text { management }\end{array}$ & Binniger et al. (2017) & $\begin{array}{l}\text { Daily management is applied in a } \\
\text { project manager routine }\end{array}$ \\
\hline & $5 \mathrm{~S}$ & Tezel and Aziz (2017b) & $\begin{array}{l}5 \mathrm{~S} \text { is implemented in highway } \\
\text { construction and maintenance }\end{array}$ \\
\hline & Kaizen event & $\begin{array}{l}\text { James, Ikuma and Nahmens } \\
\text { (2014) }\end{array}$ & $\begin{array}{l}\text { Kaizen events occur in modular } \\
\text { home manufacturing }\end{array}$ \\
\hline
\end{tabular}


Table 2 - Main BIM functionalities for the construction phase

\begin{tabular}{|c|l|}
\hline BIM functionality & \multicolumn{1}{c|}{ Description } \\
\hline 3D Visualisation & $\begin{array}{l}\text { Allows the visualisation of construction dimensions, aesthetics and form, } \\
\text { making the design intelligible in the context of the construction site, } \\
\text { especially for non-specialists or staff without much expertise (SACKS } \text { et al., } \\
\text { 2010) }\end{array}$ \\
\hline 4D Modeling & $\begin{array}{l}\text { This is the result of integrating 3D with the time variable, considering project } \\
\text { planning (RILEY, 2005; STAUB-FRENCH; KHANZODE, 2007); makes it } \\
\text { possible to simulate the construction process by considering the step-by-step } \\
\text { progress of the construction (SACKS } \text { et al., 2018) }\end{array}$ \\
\hline $\begin{array}{c}\text { SCP }- \text { Simulation of } \\
\text { the construction } \\
\text { process }\end{array}$ & $\begin{array}{l}\text { Adds temporary resources (cranes, concrete mixers, scaffolding, etc.) and } \\
\text { conducts discrete event simulation with a mode for testing construction plans } \\
\text { and project logistics (SACKS } \text { et al., 2010); different technologies can be used } \\
\text { to support the simulations, e.g., laser scanning, GPS and RFID tags (SACKS } \\
\text { et al., 2018) }\end{array}$ \\
\hline $\begin{array}{l}\text { 5D Modelling } \\
\text { VPS - Visualisation } \\
\text { of the process status }\end{array}$ & $\begin{array}{l}\text { Automated cost estimation that allows the instant generation of cost budgets, } \\
\text { adding quantified cost information to the model and facilitating project } \\
\text { management and financial monitoring (KAMARDEEN, 2010) }\end{array}$ \\
\hline $\begin{array}{l}\text { OPP/PC - Online } \\
\text { process/product } \\
\text { communication }\end{array}$ & $\begin{array}{l}\text { Bollowing a parametric model and enabling better visual control (DAVE; } \\
\text { evolution of the job site, identifying activities that are ready to start, are in } \\
\text { progress, have stopped or have been completed (SACKS } \text { et al. 2010) }\end{array}$ \\
\hline $\begin{array}{l}\text { The use of information technology and mobile devices to track and update } \\
\text { project information (SACKS } \text { et al., 2018) }\end{array}$ \\
\hline
\end{tabular}

\section{Research method}

The research strategy adopted was a systematic literature review (SLR). This strategy aims to aggregate the main existing evidence with regard to a particular research field and to point out gaps for future studies (BRERETON et al., 2007; KITCHENHAM et al., 2009). Separate SRL studies have been carried out for both BIM (SANTOS; COSTA; GRILO, 2017; LU et al., 2015; CHENG; LU; DENG, 2016) and lean construction (BAINES et al., 2006; VIANA; FORMOSO; KALSAAS, 2012: REYES, 2015).

The systematic literature review was conducted in four steps, as proposed by Morandi and Camargo (2015):

(a) defining the research question;

(b) defining the search strategy (search string, year range and sources of publications);

(c) starting the searches and refining the quantity of papers using predefined criteria; and

(d) analysing and concluding.

\section{Definition of the research question}

BIM and lean thinking were chosen as the main topics. Previous authors have studied the synergies between lean and BIM in all phases. The construction phase of the construction life cycle was defined as the focus of this study.

Based on an initial literature review, some of the main lean practices and BIM functionalities applied to the construction phase were identified.

Thus, the research question was defined as follows: "What are the hitherto unexplored opportunities for using BIM functionalities as facilitators of the implementation of lean practices in the construction phase?".

\section{Research strategy}

The first stage of the review was database selection. The Scopus and Compendex databases were chosen, as well as the proceedings of the IGLC (International Group for Lean Construction) Conference. After some 
testing, the search terms (string) used in the database were formulated: "(Lean and BIM) and (construction or building)", "(Lean and building information modeling) and (construction or building)", and "(Lean and virtual design and construction) and (construction or building)".

Regarding the proceedings of the IGLC Conference, the search was carried out using the string "BIM" or "building information modeling" or "virtual design and construction" since these proceedings specialise in lean construction.

The searches included articles published from 2003 to 2019.

\section{Searches and encoding (bibliometric data)}

The initial search resulted in a total of 532 articles. Then, a title analysis selected just the papers related to the construction phase, resulting in 250 studies. Duplicate articles were excluded (30 articles), and papers analysis based on reading the abstracts (107 articles), and full papers ( 80 papers) excluded the studies that did not actually meet the criteria for selection, resulting in 43 studies. The snowball method (references collected from the selected articles) was also adopted, which resulted in the addition of 6 articles, for a total of 49 studies selected. Figure 1 shows the numerical data for each stage of the refinement process.

The criteria for paper selection were as follows:

(a) papers having a practical application (case studies);

(b) literature review articles were considered just as a source for primary studies; and

(c) papers presenting the joint application of BIM functionalities and lean practices.

Thus, papers that applied lean practices and BIM functionalities separately were not considered.

Bibliometric data on the selected articles were then collected. The year of publication, sources of publication and types of projects were included in the data analysis.

Figure 1 - Bibliometric data on the selected articles

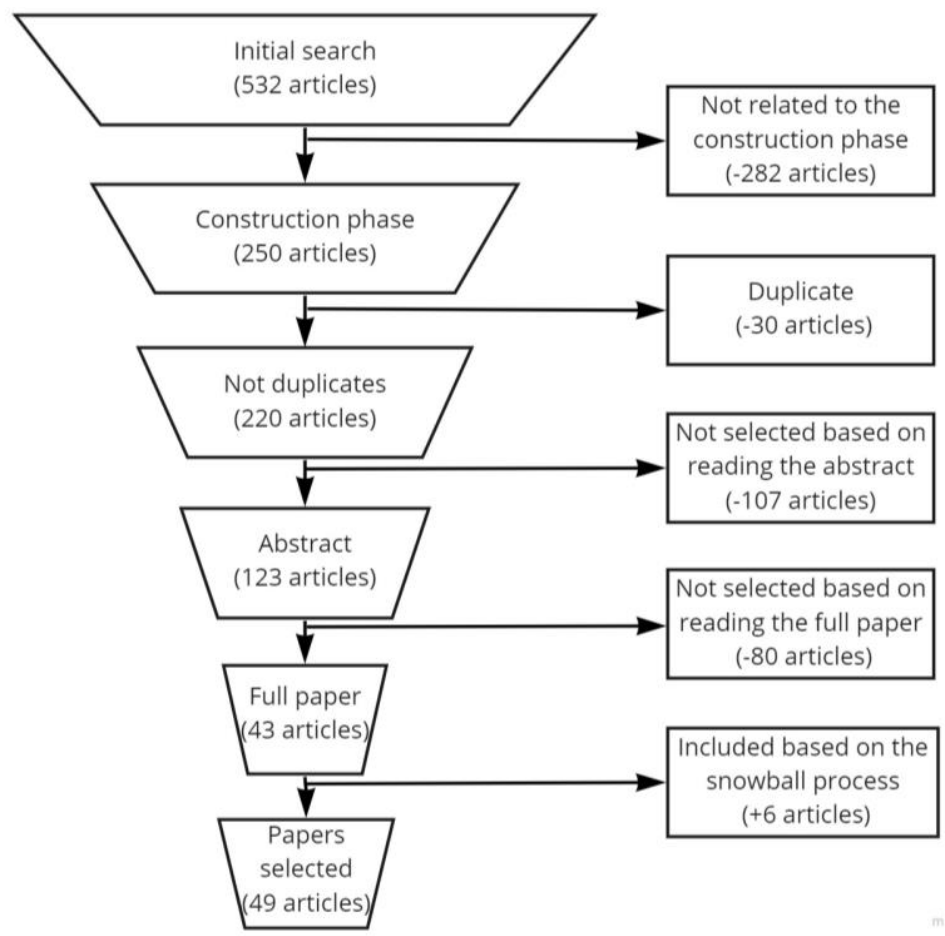




\section{Synthesis of the results}

A cross-reference matrix was organised to show the combinations of lean practices and BIM functionalities already discussed in the literature and the research gaps indicating additional potential opportunities for combinations. The analysis discussed the potential contributions of BIM functionalities to each lean practice, identifying the current state and possible advances.

Ultimately, final considerations about the main opportunities for future applications were made.

\section{Results and discussion}

\section{Bibliometric Analysis}

Based on the selected studies, Figure 2 presents the number of publications over the period of study, which ranged from 2003 to 2019 .

Figure 2 shows that the number of papers based on the selection criteria has increased over the last ten years. One hypothesis is that this increase is due to the increased use of BIM, which was in the early stages at that time.

Table 3 shows the sources of publication of the selected papers related to BIM functionalities supporting lean practices, organised by the focus of the publication (journals, books, or abstracts).

In Table 3, all 49 publications collected refer to research on lean and BIM. Over $50 \%$ of the selected articles (26 searches) were published in lean-specific research sources (the IGLC Conference and Lean Construction Journal). Nine selected studies were published in construction management journals, and 14 studies were from sources related to the area of technology in construction.

The most frequent source of the selected articles is the proceedings of the IGLC Conference (25), which is a publication that specialises in lean. The reason for the concentration of selected papers in this source is probably the pioneering paper about the synergy between lean and BIM published in the proceedings of the 2009 IGLC Conference by Sacks et al. (2009), which subsequently generated Sacks et al. (2010). Since the publication of these papers, lean and BIM have been permanent themes at the annual IGLC Conference.

On the other hand, the second most frequent source is Automation in Construction (7), which focuses on technology, and both Engineering, Construction and Architectural Management (2) and Journal of Construction Engineering and Management (2) are the third most frequent source.

As well as these four sources with the most selected articles and the 2 books, 11 different journals publishing a total of 11 papers are present in the selection, showing that interest in the subject has spread to different research forums related to lean, management and technology.

Figure 2 - Number of publications over the period of study

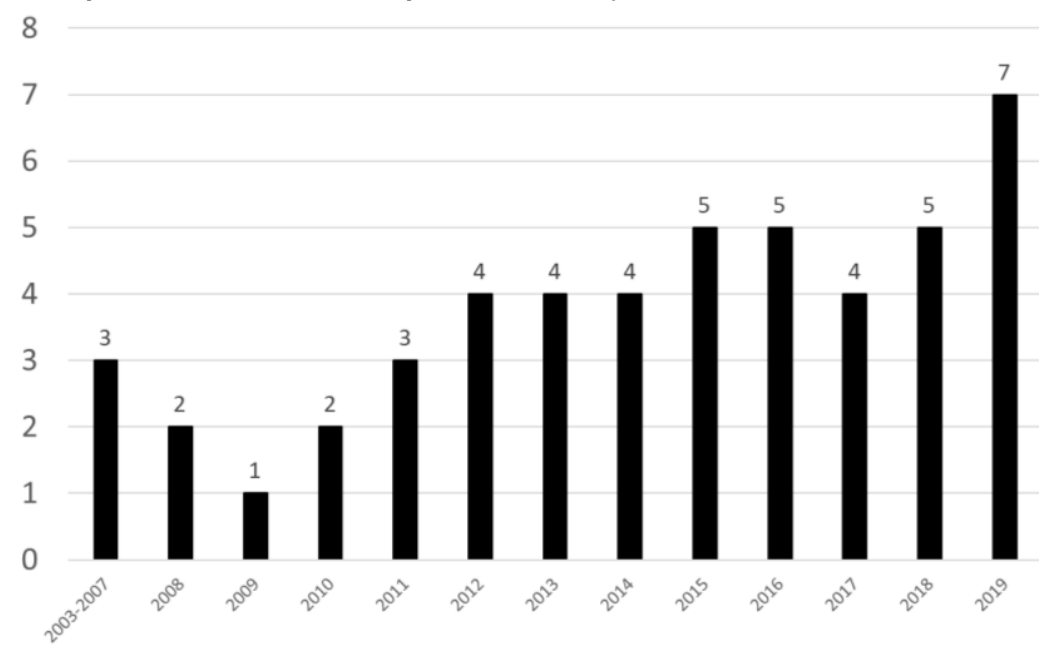

314 Mariz, R. N.; Picchi, F. A. 
Table 3 - Source of publication related to BIM functionalities supporting lean practices in the construction phase

\begin{tabular}{|c|c|c|c|}
\hline Publication & $\begin{array}{l}\text { Number } \\
\text { of papers }\end{array}$ & \begin{tabular}{|c|} 
Publication \\
focus
\end{tabular} & $\begin{array}{c}\text { Paper subtotals } \\
\text { by publication } \\
\text { focus }\end{array}$ \\
\hline IGLC Conference & 25 & \multirow{2}{*}{ Lean } & \multirow{2}{*}{26} \\
\hline Lean Construction Journal & 1 & & \\
\hline $\begin{array}{l}\text { Engineering, Construction and Architectural } \\
\text { Management }\end{array}$ & 2 & \multirow{7}{*}{ Management } & \multirow{7}{*}{9} \\
\hline Journal of Construction Engineering and Management & 2 & & \\
\hline $\begin{array}{l}\text { Implementing lean in construction: Lean construction } \\
\text { and BIM* }\end{array}$ & 1 & & \\
\hline Canadian Journal of Civil Engineering & 1 & & \\
\hline Construction Management and Economics & 1 & & \\
\hline Construction Research Congress & 1 & & \\
\hline International Journal of Construction Management & 1 & & \\
\hline Automation in Construction & 7 & \multirow{8}{*}{ Technology } & \multirow{8}{*}{14} \\
\hline BIM Handbook* & 1 & & \\
\hline Computing in Civil and Building Engineering & 1 & & \\
\hline Construction Innovation & 1 & & \\
\hline $\begin{array}{l}\text { Electronic Journal of Information Technology in } \\
\text { Construction }\end{array}$ & 1 & & \\
\hline Journal of Computing in Civil Engineering & 1 & & \\
\hline $\begin{array}{l}\text { Journal of Mathematics Science and Technology } \\
\text { Education }\end{array}$ & 1 & & \\
\hline $\begin{array}{l}\text { The Open Construction and Building Technology } \\
\text { Journal }\end{array}$ & 1 & & \\
\hline TOTAL & 49 & & 49 \\
\hline
\end{tabular}

Note: *books were included based on the snowball method.

Love (2002) classifies the types of building projects as residential buildings, medical centers, commercial buildings, schools, public facilities and industrial buildings, and Cheng, Lu and Deng (2016) classify the types of infrastructure projects as bridges, roads, railways, tunnels, energy infrastructure, power generation, oil and gas, mines, utility infrastructure, utility infrastructure, recreational facilities, water management infrastructure, airports, ports and harbours. Based on this classification, an adaptation was made to identify the types of projects on which the selected articles focused (Figure 3).

Figure 3 shows a large concentration of applications in building projects, specifically in residential buildings and medical centers. On the other hand, there are few applications in civil infrastructure projects. BIM functionalities and lean practices have not yet been applied in some types of projects, such as bridges, tunnels, energy infrastructure, energy generation, mines, public facilities, recreational facilities, and water management infrastructure. This analysis provides insights for possible future applications.

\section{Data cross-checking: BIM functionalities vs. Lean practices}

The 49 selected papers were analysed and are identified in Table 4, which represents the cross-checking of content related to BIM functionalities and lean practices.

\section{Emerging classification of the degree of application}

Table 4 shows that a clear differentiation of lean practices emerges based on the degree of reported application of BIM functionalities. For example, LPS was referred to in 43 articles, while four lean practices were not mentioned at all.

Observing Table 4, we adopted a classification based on the number of selected papers per lean practice. One lean practice has been extensively explored (43 papers), three have been reasonably explored (7 to 9 papers), five have been preliminarily explored (1 or 2 papers), and five are currently unexplored (zero papers). The lean practices for each classification are shown in Table 5 and are discussed below. 
Figure 3 - Project types

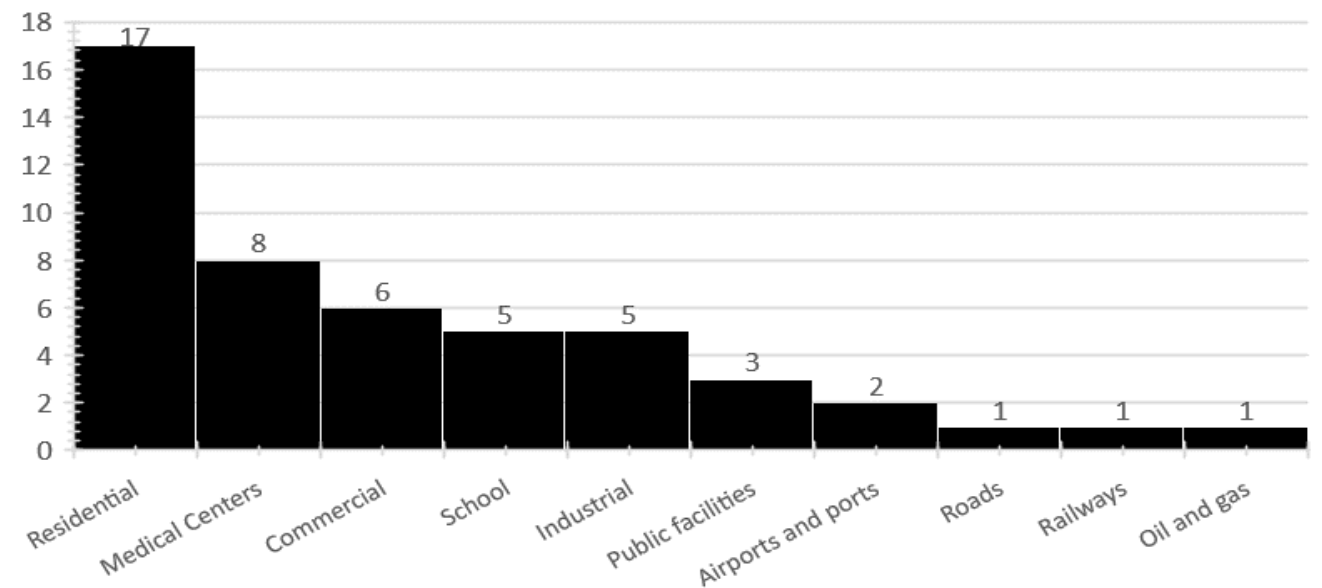

Table 4 - Cross-checking of the relationships among BIM functionalities and lean practices in the construction phase based on the literature

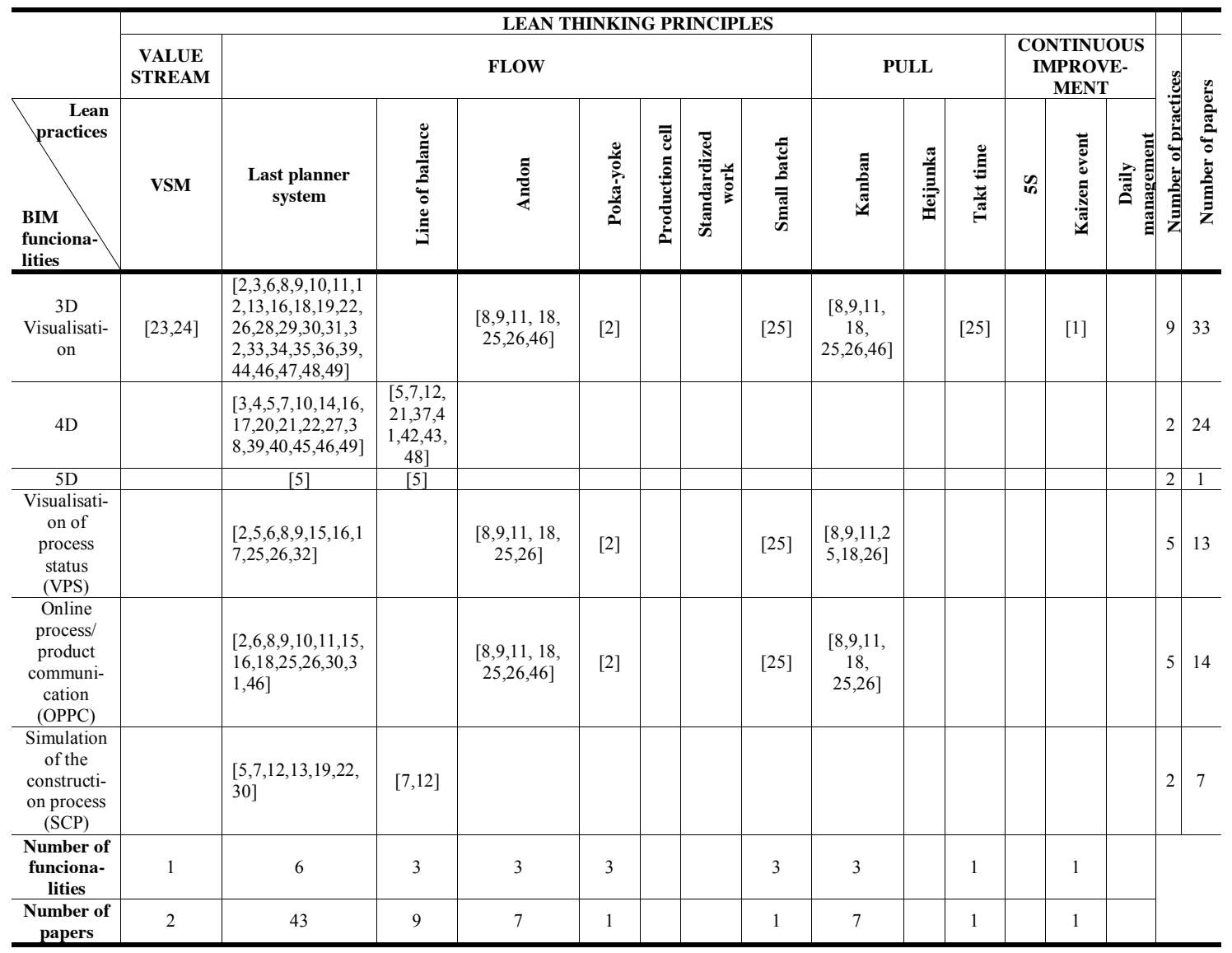

Note: Caption: 1 Sacks et al. (2018); 2 Dave, Boddy and Koskela (2011); 3 Bhatla and Leite (2012); 4 Hyatt (2011); 5 Scheer et al. (2014); 6 Dave et al. (2013); 7 Bortolini, Shigaki and Formoso (2015); 8 Sacks et al. (2011); 9 Sacks et al. (2012); 10 lbarra et al. (2016); 11 Liu and Shi (2017); 12 Ben-Alon and Sacks (2015); 13 Clemente and Cachadinha (2013); 14 Dave et al. (2013); 15 Dave et al. (2014); 16 Dave et al. (2016); 17 Gerber, Gerber and Kunz (2010); 18 Gurevich and Sacks (2014); 19 Hamdi and Leite (2014); 20 Harris and Alves (2013); 21 Kemmer et al. (2016); 22 Mahalingam, Yadav and Varaprasad (2015); 23 Moghadam, Alwisy and Al-Hussein (2012); 24 Nath et al. (2015); 25 Sacks, Treckmann and Rozenfeld (2009); 26 Sacks, Radosavljevic and Barak (2010); 27 Sriprasert and Dawood (2003); 28 Tillmann and Sargent (2016); 29 Toledo, Olivares and González (2016); 30 Wen (2014); 31 Fosse, Ballard and Fischer (2017); 32 Von Heyl and Teizer (2017); 33 Zeng, König and Teizer (2017); 34 Zhang et al. (2018); 35 Koseoglu and Gunes (2018); 36 Matta et al. (2018); 37 Vargas,

Bataglin and Formoso (2018); 38 Bataglin et al. (2019); 39 Heigermosera et al. (2019); 40 Koseoglu, Sakin and Arayicy (2018); 41 StaubFrench, Russel and Tran (2008); 42 Jongeling and Olofsson (2007); 43 Björnfot and Jongeling (2007); 44 Wang et al. (2016); 45 Bortolini, Formoso and Viana (2019); 46 McHugh, Dave and Craig (2019); 47 Dallasega et al. (2019); 48 Gómez-Sánchez, Ponz-Tienda and RomeroCortés (2019); and 49 Álvares and Costa (2019). 


\section{Extensively explored practice}

The last planner system (LPS) appears in Tables 4 and 5 as the only lean practice with applications of BIM functionalities that, to date, has been extensively explored. Mentioned by 43 articles, LPS was applied for all six BIM functionalities discussed. This result is probably a consequence of the fact that LPS has been one of the most commonly used lean practices in construction for a long period of time.

Ibarra et al. (2016) used LPS integrated with Autodesk 360 to track a project's progress and to carry out quality control. Bhatla and Leite (2012) proposed a framework for integrating BIM and LPS, while Tillman and Sargent (2016) investigated opportunities for further integrating BIM and LPS. Toledo, Olivares and González (2016) analysed 2 project cases: one using only an LPS and another employing an LPS integrated with BIM. The authors concluded that the LPS integrated with BIM provides better results and several benefits. Kemmer et al. (2016) analysed the use of the last planner system and 4D modelling in a retrofit project as a means of reducing the interruption of property usage. Bortolini, Formoso and Viana (2019) applied LPS and 4D to simulate logistics in an industrial plant.

Workflow systems, such as Lewis (SRIPRASERT; DAWOOD, 2003), KanBIM (SACKS; RADOSAVLJEVIC; BARAK, 2010) and VisiLean (DAVE et al., 2011), use LPS to assist in project management, employing BIM to make it more visual. When associated with a parametric model and PPC (planning and production control) activities, work control becomes faster and intuitive.

Based on an analysis of the five macro steps of the last planner system, i.e., milestone planning, phase planning, make-ready planning, commitment planning and daily huddles (BALLARD; TOMMELEIN, 2016; EBBS; PASQUIRE, 2019), there is a large concentration of applications in make-ready planning and commitment planning. This result suggests that there are opportunities to explore the other macro steps, especially daily huddles, and it demonstrates that even though the LPS has, to date, been the most studied lean practice considering BIM support, it can be further enhanced by using BIM functionalities in all of its macro steps.

\section{Reasonably explored practices}

Table 5 shows that three lean practices have been reasonably explored by a considerable number of papers, i.e., 7 to 9. These practices are the line of balance, Andon and Kanban.

Articles related to the line of balance focus on three BIM functionalities: 4D, 5D and simulation of the construction process. In contrast, articles about Andon and Kanban concentrate on the other three BIM functionalities: 3D visualisation, visualisation of the process status, and online process/product communication.

This result suggests that some lean practices demand functionalities that are more adequate for planning and simulation (4D, 5D and simulation of the construction process), while others need support from functionalities that are more related to visualisation and communication (3D visualisation, visualisation of the process status, online process/product communication).

Table 5 - Degree of application of BIM functionalities in lean practices

\begin{tabular}{c|c|c|c|c}
\hline \multirow{4}{*}{$\begin{array}{c}\text { Number of } \\
\text { papers }\end{array}$} & \multicolumn{4}{|c}{ Degree of reported applications of BIM functionalities } \\
\cline { 2 - 5 } & Extensively explored & $\begin{array}{c}\text { Reasonably } \\
\text { explored }\end{array}$ & $\begin{array}{c}\text { Preliminarily } \\
\text { explored }\end{array}$ & Not explored \\
\cline { 2 - 5 } & Last planner system & Line of balance & VSM & Production cell \\
\cline { 2 - 5 } & & Andon & Poka-yoke & Standardised work \\
\cline { 2 - 5 } Lean practices & & Kanban & Small batch & Heijunka \\
\cline { 2 - 5 } & & & Takt time & $5 \mathrm{~S}$ \\
\cline { 2 - 5 } & & & Kaizen event & Daily management \\
\hline \multirow{4}{*}{$\begin{array}{c}\text { Number of lean } \\
\text { practices }\end{array}$} & 1 & 3 & 5 & 5 \\
\hline
\end{tabular}


Ben-Alon and Sacks (2015) used agent-based simulation (ABS) to simulate the execution of some activities, demonstrating their results through a flowline (a concept related to the line of balance). Jongeling and Olofsson (2007), Björnfot and Jongeling (2007), Staub-French, Russel and Tran (2008), Scheer et al. (2014) and Bortolini, Shigaki and Formoso. (2015) used a line of balance as the basis for 4D planning, demonstrating the potential gains of this interaction for planning visualisation and interference identification.

Andon and Kanban appear frequently due to their use in the KanBIM workflow system, which employs these practices to signal the execution status of activities in a project.

"4D modeling" is concentrated in just 2 lean practices (the line of balance and last planner system), indicating its strong relationship with these two practices. This result demonstrates the importance of combining BIM and planning techniques (SEPPÄNEN; MODRICH; BALLARD, 2015); however, such combinations could still be enhanced through 4D modeling.

Lewis, KanBIM, and VisiLean integrate BIM functionalities with LPS, Andon, and Kanban. Additional software connections could use line of balance with 4D, offering more planning options.

This group of practices has already been the subject of discussions of applications of BIM functionalities by different authors, but there could be additional opportunities for exploration, as discussed in the next section.

\section{Preliminarily explored practices}

Tables 4 and 5 show that five lean practices were mentioned in only 1 or 2 articles. These practices are VSM, poka-yoke, small batch, kaizen events, and takt time.

These studies can be considered pioneers, leaving plenty of opportunities for further exploration. For example, only poka-yoke was mentioned regarding three BIM functionalities (3D, VPS, OP/PC); the other four lean practices in this group were discussed only for $3 \mathrm{D}$ visualisation applications. Several other potential applications for supporting these practices can be identified, as discussed below.

Takt-time is a fundamental lean concept that aligns the production rhythm to customer demand, and in the construction context, it has been associated with the planning stage (FRANDSON; BERGHEDE; TOMMELEIN, 2013) and with potential relationships with 4D simulation parameters.

The application of the small batch concept is strongly associated with continuous flow and has also been used in construction in the planning phase (DLOUHY; BINNINGER; HAGHSHENO, 2019). These practices can also be used in planning software that is facilitated by the integration of BIM functionalities, especially 3D, 4D and SCP, allowing different scenario simulations with better visualisation to make faster decisions.

Kaizen events and VSMs can be applied at any stage of the construction phase. BIM functionalities could optimise data collection and processing.

\section{Not explored practices}

Five practices - production cells, standardised work, Heijunka, 5S and daily management - have no mentions in the selected papers.

These practices are frequently mentioned by practitioners and researchers as fundamental elements for the implementation of lean principles, and the lack of research on these practices with regard to applications of BIM functionalities reveals a major opportunity.

Heijunka could also be implemented in the planning phase to level production and resources. 3D, 4D, and SCP would facilitate this practice.

5S, production cells and standardised work could use 4D and SCP to simulate the micro planning of construction activities, detailing the design of the work layout, stock location, material movement routes, etc.

Daily management could be supported by the optimisation of data collection at the construction site using online process/product communication and visualisation of process status.

\section{Auxiliary technologies}

Tezel and Aziz (2017a) proposed some auxiliary technologies that can enhance the use of BIM:

(a) mobile computing \& wearable devices;

318 Mariz, R. N.; Picchi, F. A. 
(b) the Internet of Things (IoT);

(c) context-aware systems;

(d) AutoID (RFID); and

(e) virtual and augmented reality systems; and surface scanning (laser scanning, photogrammetry).

Table 6 presents the use of these auxiliary technologies to enhance the synergies between BIM functionalities and lean practices based on the literature.

Auxiliary technologies are mentioned in 19 papers. The most mentioned auxiliary technology is mobile computing (16), mainly due to the use of mobile devices (tablets, cell phones).

Other technologies have been little explored. For example, Dave et al. (2016) used the IOT, and Wang et al. (2016) used RFID connected to a 3D BIM model to control material constraints. Virtual reality CAVEs (virtual and augmented reality systems) have been used to guide the performance of "virtual" work in a building with sixteen apartments (GUREVICH; SACKS, 2014). Touchscreen TVs integrated with BIM that are used in job sites are mentioned as resources for employee communication (SACKS et al., 2011; LIU; SHI, 2017).

\section{Discussion}

Table 7 summarises the applications found in the literature and the potential applications, as discussed in the previous sections. For all lean practices, interesting additional combinations can be observed, demonstrating that the synergies between lean and BIM have large room for further development.

Table 6 - Auxiliary technologies that enable BIM and lean interaction

\begin{tabular}{|c|c|c|c|c|c|c|}
\hline Authors & $\begin{array}{c}\text { Mobile } \\
\text { computing } \\
\text { (\& } \\
\text { wearable } \\
\text { devices) }\end{array}$ & $\begin{array}{c}\text { The } \\
\text { Internet } \\
\text { of Things } \\
\text { (IoT) }\end{array}$ & $\begin{array}{l}\text { Context- } \\
\text { aware } \\
\text { systems }\end{array}$ & $\begin{array}{c}\text { AutoID } \\
\text { (RFID, } \\
\text { NFC) }\end{array}$ & $\begin{array}{l}\text { Virtual and } \\
\text { augmented } \\
\text { reality } \\
\text { systems }\end{array}$ & $\begin{array}{l}\text { Surface scanning } \\
\text { (laser scanning, } \\
\text { photogrammetry) }\end{array}$ \\
\hline Dave et al. (2013) & $\mathrm{x}$ & & $\mathrm{x}$ & $\mathrm{x}$ & & \\
\hline Sacks et al. (2011) & $\mathrm{x}$ & & & & & \\
\hline Sacks et al. (2012) & $\mathrm{x}$ & & & & & \\
\hline \multicolumn{7}{|l|}{ Ibarra et al. (2016) } \\
\hline Liu and Shi (2017) & $\mathrm{x}$ & & & & & \\
\hline Dave et al. (2014) & $\mathrm{x}$ & $\mathrm{x}$ & & & & \\
\hline Dave et al. (2016) & $\mathrm{x}$ & $\mathrm{x}$ & $\mathrm{x}$ & $\mathrm{x}$ & & \\
\hline Gurevich and Sacks (2014) & & & & & $\mathrm{x}$ & \\
\hline Hamdi and Leite (2014) & $\mathrm{x}$ & & & & & \\
\hline $\begin{array}{c}\text { Sacks, Radosavljevic and } \\
\text { Barak (2010) }\end{array}$ & $\mathrm{x}$ & & & & & \\
\hline $\begin{array}{l}\text { Sriprasert and Dawood } \\
(2003)\end{array}$ & $\mathrm{x}$ & & & & & \\
\hline Tillmann and Sargent (2016) & $\mathrm{x}$ & & & & & \\
\hline $\begin{array}{l}\text { Fosse, Ballard and Fischer } \\
(2017)\end{array}$ & $\mathrm{x}$ & & & & & \\
\hline Von Heyl and Teizer (2017) & $\mathrm{x}$ & $\mathrm{x}$ & & & & \\
\hline Zhang et al. (2018) & $\mathrm{x}$ & & & & & \\
\hline Koseoglu and Gunes (2018) & $\mathrm{x}$ & & & & & \\
\hline $\begin{array}{l}\text { Koseoglu, Sakin and } \\
\text { Arayicy (2018) }\end{array}$ & $\mathrm{x}$ & & & & & \\
\hline $\begin{array}{c}\text { McHugh, Dave ad Craig } \\
\text { (2019) }\end{array}$ & $\mathrm{x}$ & & & & & \\
\hline Álvares e Costa (2019) & & & & & & $\mathrm{x}$ \\
\hline Total & 16 & 3 & 2 & 2 & 1 & 1 \\
\hline
\end{tabular}


Table 7 - Lean practices supported by BIM functionalities - application and suggestion for future research

\begin{tabular}{|c|c|c|}
\hline Lean Practices & Already Applied & Opportunities for future applications \\
\hline Line of balance & $\begin{array}{l}\text { Software programs are using 4D and simulation of the } \\
\text { construction process with the line of balance to enable } \\
\text { work progress visualisation. Thus, it is possible to } \\
\text { plan work by location, simulate the workflow, and } \\
\text { through the model see the progress and potential team } \\
\text { interfaces in a clearer and easier way. }\end{array}$ & $\begin{array}{l}\text { Only one article presented a connection with } 5 \mathrm{D} \text {, } \\
\text { providing an opportunity for exploration in further studies. } \\
\text { In addition, lean integrated planning methodologies could } \\
\text { be enhanced by BIM functionalities, especially 4D, } \\
\text { simulation of the construction process and visualisation of } \\
\text { process status. }\end{array}$ \\
\hline Kanban & $\begin{array}{l}\text { The Kanban concept used in the selected articles is } \\
\text { associated with the work-in-progress status using a } \\
\text { virtual model. In other words, through virtual } \\
\text { information, the workflow management system } \\
\text { provides information to the production teams on the } \\
\text { activities that can be initiated. }\end{array}$ & $\begin{array}{l}\text { Online process/product communication functionality can } \\
\text { be applied to control the consumption status and track the } \\
\text { positioning of materials on the job site with a virtual } \\
\text { model. }\end{array}$ \\
\hline VSM & $\begin{array}{l}\text { VSM has been used together with BIM to facilitate } \\
\text { modular and prefabricated construction. Additional } \\
\text { steps and rework have been identified by CAD } \\
\text { drawings; thus, with the implementation of VSM and } \\
\text { 3D visualisation, there is an increase in the } \\
\text { productivity gains of production teams. }\end{array}$ & $\begin{array}{l}\text { Simulation could be performed to understand the current } \\
\text { state and mainly to design the future state. Several } \\
\text { possible scenarios could be produced through simulation } \\
\text { of the construction process and 4D. }\end{array}$ \\
\hline Small batch & $\begin{array}{l}\text { Small batches have been used to update the } \\
\text { construction status using a board. They have been } \\
\text { used to update a system every } 10 \text { minutes in the } \\
\text { model. Small batches have been integrated with the } \\
\text { online process/product communication functionality } \\
\text { (DAVE } \text { et al., 2016). }\end{array}$ & $\begin{array}{l}\text { Small batches are a practice with wide applicability since } \\
\text { use in macro planning until execution and control phase } \\
\text { can be facilitated by several BIM functionalities ( } 3 \mathrm{D}, 4 \mathrm{D} \text {, } \\
\text { and simulation of the construction process). }\end{array}$ \\
\hline Takt time & $\begin{array}{l}\text { Takt time has been used in KanBIM. When any status } \\
\text { duration is longer than the takt time, it indicates } \\
\text { bottlenecks in the model (SACKS; TRECKMANN; } \\
\text { ROZENFELD, 2009). }\end{array}$ & $\begin{array}{l}\text { Planning software could use takt time to simulate different } \\
\text { scenarios and for a better visualisation for faster decision } \\
\text { making ( } 3 \mathrm{D}, 4 \mathrm{D} \text {, and simulation of the construction } \\
\text { process functionalities). }\end{array}$ \\
\hline Kaizen event & $\begin{array}{l}\text { Kaizen events have applied 3D visualisation to } \\
\text { improve constructability in an automotive factory. } \\
\text { The results were waste and cost reductions (SACKS et } \\
\text { al., 2018). }\end{array}$ & $\begin{array}{l}\text { Kaizen events can be used to solve any type of problem } \\
\text { and at any construction stage. }\end{array}$ \\
\hline Production cell & - & $\begin{array}{l}\text { 3D, 4D, and simulation of the construction process } \\
\text { simulations could be performed to define teams' work } \\
\text { layout, logistics and inventory positioning. }\end{array}$ \\
\hline $\begin{array}{l}\text { Standardised } \\
\text { work }\end{array}$ & - & $\begin{array}{l}\text { 4D and simulation of the construction process can be used } \\
\text { for micro planning and training of production workers. }\end{array}$ \\
\hline Heijunka & - & $\begin{array}{l}\text { Heijunka can be used in planning software to balance and } \\
\text { level resources, which can be aided by 3D visualisation } \\
\text { and 4D simulation. }\end{array}$ \\
\hline
\end{tabular}




\section{Conclusion}

Lean implementations depend on people understanding lean principles and why and how they can apply lean to their environment and business needs, deploying it on an operational basis. The appropriate use of BIM functionalities to support lean practices is an important facilitator of successful lean transformations.

To systematically understand what has already been done and potential opportunities, a set of lean practices and BIM functionalities was used for a cross-check of the coverage of applications.

Below, we summarise the main conclusions in three blocks: bibliometric analysis, the degree of application of BIM to support lean practices and gaps and opportunities.

The bibliometric analysis showed that:

(a) the number of papers on the subject has grown in the last ten years, probably as a tendency due to the increased use of BIM (Figure 2);

(b) the synergies between BIM and lean practices in the construction phase are reported in publications with diverse focuses, such as lean, management and technology, showing the cross interest in different research forums (Table 3); e

(c) the reported cases mainly involve building projects, with scarce research on the synergies between lean and BIM in infrastructure projects (Figure 3).

A classification of the degree of application of BIM functionalities to specific lean practices emerged: practices that have been extensively explored, reasonably explored, and just preliminarily explored (Table 5):

(a) just one lean practice (the last planner system) has been extensively explored;

(b) three have been reasonably explored (the line of balance, Andon and Kanban);

(c) five have just been preliminarily explored (VSM poka-yoke, small batches, and Kaizen events); and

(d) five have not been explored (production cells, standardised work, Heijunka, and daily management).

From this classification, the main aspects already addressed, as well as the main gaps and opportunities were identified for further research (Table 7):

(a) the results show that although applications exist, BIM is still underused to support lean, and as a result, fundamental lean practices that could possibly provide support currently remain underexplored;

(b) even for practices that have been extensively explored and reasonably explored, several applications of BIM functionalities were identified that could be further explored, as presented in Table 7;

(c) major opportunities that, to date, have not been explored are related to the use of BIM functionalities to support applications of lean practices in the gemba (the real place where things are done). This can be seen in Table 7, where not explored lean practices typically focus on the field, such as production cells, standardised work, Heijunka 5S, and daily management. Training and communication to spread the use of lean tools to the workforce facilitated by BIM is also a less explored opportunity;

(d) taking management construction activities, i.e., planning, logistics, execution and control, as a reference for an analysis with a closer connection to practical use, the research pointed out that planning is the activity with the most coverage (e.g., the last planner system and line of balance), followed by logistics (e.g., Kanban and small batches), with major opportunities in execution (gemba, as mentioned above) and control (e.g., daily management) (Table 7); and

(e) auxiliary technologies are opportunities for combined use with BIM, enhancing lean practice applications. Mobile computing is mentioned in several selected papers, but with regard to other technologies (such as the IoT, RFID, virtual reality, augmented reality), there is scarce research on the specific use of lean practices for support (Table 6).

The research identified extensive opportunities for BIM functionalities to support fundamental lean practices that currently have no support or scarce support. This is a massive challenge for practitioners and researchers, mainly because both lean and BIM are concepts that still depend on cultural changes in the construction industry for their extended use. 


\section{References}

ÁLVARES, J. S.; COSTA, D. B. Construction progress monitoring using unmanned aerial system and 4D BIM. In: ANNUAL CONFERENCE OF THE INTERNATIONAL GROUP FOR LEAN CONSTRUCTION, 27., Dublin, 2019. Proceedings [...] Dublin: IGLC, 2019.

ALVES, T. D. C. et al. Incentives and innovation to sustain lean construction implementation. In: ANNUAL CONFERENCE OF THE INTERNATIONAL GROUP FOR LEAN CONSTRUCTION, 17., Taipei, 2009. Proceedings [...] Taipei: IGLC, 2009.

ARBULU, R.; BALLARD, G.; HARPER, N. Kanban in construction. In: ANNUAL CONFERENCE OF THE INTERNATIONAL GROUP FOR LEAN CONSTRUCTION, 17., Virginia, 2003. Proceedings [...] Virginia: IGLC, 2003.

ARDITI, D.; TOKDEMIR, O. B.; SUH, K. Challenges in line-of-balance scheduling. Journal of Construction, Engineering and Management, v. 128, n. 6, p.545-556, 2002.

BAINES, T. et al. State-of-the-art in lean design engineering: a literature review on white-collar lean. Journal of Engineering Manufacture, v. 220, n. 9, p. 1539-1547, 2006.

BALlARD, G.; HOWELL, G. A. An Update on Last Planner. In: ANNUAL CONFERENCE OF THE INTERNATIONAL GROUP FOR LEAN CONSTRUCTION, 17., Virginia, 2003. Proceedings [...] Virginia: IGLC, 2003.

BALLARD, G.; TOMMELEIN, I. Current process benchmark for the Last Planner System. Lean Construction Journal, Berkeley, p. 57-89, 2016.

BARBOSA, G. et al. Heijunka system to level telescopic forklift activities using tablets in construction site. In: ANNUAL CONFERENCE OF THE INTERNATIONAL GROUP FOR LEAN CONSTRUCTION, 21. Fortaleza, 2013. Proceedings [...] Fortaleza: IGLC, 2013.

BATAGLIN, F. S. et al. Model for planning and controlling the delivery and assembly of engineer-to-order prefabricated building systems: exploring synergies between Lean and BIM. Canadian Journal of Civil Engineering, v. 47, n. 2, p. 165-177, 2019.

BEN-ALON, L.; SACKS, R. Simulating and visualizing emergent production in construction (epic) using agents and BIM. In: ANNUAL CONFERENCE OF THE INTERNATIONAL GROUP FOR LEAN CONSTRUCTION, 23., Perth, 2015. Proceedings [...] Perth: IGLC, 2015.

BHATLA, A.; LEITE, F. Integration framework pf BIM with the Last Planner System. In: ANNUAL CONFERENCE OF THE INTERNATIONAL GROUP FOR LEAN CONSTRUCTION, 20., San Diego, 2012. Proceedings [...] San Diego: IGLC, 2012.

BINNINGER, M. et al. How can lean construction improve the daily schedule of a construction manager.In: IOP CONF. SERIES: MATERIALS SCIENCE AND ENGINEERING, 245., Prague, 2017. Proceedings [...] Prague: IOP, 2017.

BIOTTO, C. et al. Adapted use of andon in a horizontal residential construction project. In: ANNUAL CONFERENCE OF THE INTERNATIONAL GROUP FOR LEAN CONSTRUCTION, 22., Oslo, 2014. Proceedings [...] Oslo: IGLC, 2014.

BJÖRNFOT, A.; JONGELING, R. Application of line- of- balance and 4D CAD for lean planning. Construction Inovation, v. 7, n. 2, p. 200-211, 2007.

BORTOLINI, R.; FORMOSO, C. T.; VIANA, D. D. Site logistics planning and control for engineer-toorder prefabricated building systems using BIM 4D modeling. Automation in Construction, v. 98, p. 248264, 2019.

BORTOLINI, R.; SHIGAKI, J. S.; FORMOSO, C. T. Site logistic planning and control using 4D modeling: a study in a lean car factory building site. In: ANNUAL CONFERENCE OF THE INTERNATIONAL GROUP FOR LEAN CONSTRUCTION, 23., Perth, 2015. Proceedings [...] Perth: IGLC, 2015.

BRERETON, P. et al. Lessons from applying the systematic literature review process within the software engineering domain. Journal of Systems and Software, v. 80, p. 571-583, 2007. 
BULHÕES, I. R.; PICCHI, F. A.; GRANJA, A. D. Combining value stream and process levels analysis for continuous flow implementation in construction. In: ANNUAL CONFERENCE OF THE INTERNATIONAL GROUP FOR LEAN CONSTRUCTION, 13., Sidney, 2005. Proceedings [...] Sidney: IGLC, 2005.

CARNEIRO, A. Q. et al. Development and evolution of project production systems: the PS-37. In: ANNUAL CONFERENCE OF THE INTERNATIONAL GROUP FOR LEAN CONSTRUCTION, 17. Taipei, 2009. Proceedings [...] Taipei: IGLC, 2009.

CHENG, J. C. P.; LU, Q.; DENG, Y. Analytical review and evaluation of civil information modeling. Automation in Construction, v. 67, p. 31-47, 2016.

CLEMENTE, J.; CACHADINHA, N. BIM-Lean synergies in the management on MEP works in public facilities of intensive use: a case study. In: ANNUAL CONFERENCE OF THE INTERNATIONAL GROUP FOR LEAN CONSTRUCTION, 21., Fortaleza, 2013. Proceedings [...] Fortaleza: IGLC, 2013.

DALLASEGA, P. et al. BIM-based construction progress measurement of non-repetitive HVAC installation works. In: ANNUAL CONFERENCE OF THE INTERNATIONAL GROUP FOR LEAN CONSTRUCTION, 27., Dublin, 2019. Proceedings [...] Dublin: IGLC, 2019.

DAVE, B. et al. Addressing information flow in lean production management and control in construction. In: ANNUAL CONFERENCE OF THE INTERNATIONAL GROUP FOR LEAN CONSTRUCTION, 22. Oslo, 2014. Proceedings [...] Oslo: IGLC, 2014.

DAVE, B. et al. Implementing lean in construction: Lean construction and BIM. London, 2013. Manual, CIRIA.

DAVE, B. et al. Opportunities for enhanced lean construction management using Internet of Things standards. Automation in Construction, v. 61, p. 86-97, 2016.

DAVE, B.; BODDY, S.; KOSKELA, L. Challenges and opportunities in implementing Lean and Bim on an infrastructure project. In: ANNUAL CONFERENCE OF THE INTERNATIONAL GROUP FOR LEAN CONSTRUCTION, 21., Fortaleza, 2013. Proceedings [...] Fortaleza: IGLC, 2013.

DAVE, B.; BODDY, S.; KOSKELA, L. Visilean: designing a production management system with lean and Bim. In: ANNUAL CONFERENCE OF THE INTERNATIONAL GROUP FOR LEAN CONSTRUCTION, 19., Lima, 2011. Proceedings [...] Lima: IGLC, 2011.

DLOUHY, J.; BINNINGER, M; HAGHSHENO, S. Buffer management in takt planning - an overview of buffers in takt systems'. In: ANNUAL CONFERENCE OF THE INTERNATIONAL GROUP FOR LEAN CONSTRUCTION, 27., Dublin, 2019. Proceedings [...] Dublin: IGLC, 2019.

EBBS, P.; PASQUIRE, C. A facilitators' guide to the Last Planner ${ }^{\circledR}$ System: a repository of facilitation tips for practitioners. Nottingham: Nottingham Trent University, 2019.

FERNANDES, N. B. L. S. et al. The standardized work tool applied to the waterproofing process with acrylic membrane. In: ANNUAL CONFERENCE OF THE INTERNATIONAL GROUP FOR LEAN CONSTRUCTION, 21., Fortaleza, 2013. Proceedings [...] Fortaleza: IGLC, 2013.

FORMOSO, C. T.; MOURA, C. B. Evaluation of the impact of the last planner system on the performance of construction project. In: ANNUAL CONFERENCE OF THE INTERNATIONAL GROUP FOR LEAN CONSTRUCTION, 17., Taipei, 2009. Proceedings [...] Taipei: IGLC, 2009.

FOSSE, R.; BALLARD, G.; FISCHER, M. Virtual design and construction: aligning BIM and Lean in practice. In: ANNUAL CONFERENCE OF THE INTERNATIONAL GROUP FOR LEAN CONSTRUCTION, 25., Heraklion, 2017. Proceedings [...] Heraklion: IGLC, 2017.

FRANDSON, A.; BERGHEDE, K.; TOMMELEIN, I. Takt-time planning for construction of exterior cladding. In: ANNUAL CONFERENCE OF THE INTERNATIONAL GROUP FOR LEAN CONSTRUCTION, 21., Fortaleza, 2013. Proceedings [...] Fortaleza: IGLC, 2013.

GERBER, D. J.; GERBER, B.; KUNZ, A. Building Information Modeling and Lean Construction: technology, methodology and advances from practice. In: ANNUAL CONFERENCE OF THE INTERNATIONAL GROUP FOR LEAN CONSTRUCTION, 18., Haifa, 2010. Proceedings [.... Haifa: IGLC, 2010. 
GÓMEZ-SÁNCHEZ, J. M.; PONZ-TIENDA, J. L.; ROMERO-CORTÉS, J. P. Lean and BIM implementation in Colombia: interactions and lessons learned. In: ANNUAL CONFERENCE OF THE INTERNATIONAL GROUP FOR LEAN CONSTRUCTION, 27., Dublin, 2019. Proceedings [...] Dublin: IGLC, 2019.

GUREVICH, U.; SACKS, R. Examination of the effects of a KanBIM production control system on subcontractors' task selections in interior Works. Automation in Construction, v. 37, p. 81-87, 2014.

HAMDI, O.; LEITE, F. BIM and Lean interactions from the BIM capability maturity model perspective: a case study. In: ANNUAL CONFERENCE OF THE INTERNATIONAL GROUP FOR LEAN CONSTRUCTION, 22., Oslo, 2014. Proceedings [...] Oslo: IGLC, 2014.

HARRIS, B.; ALVES, T. D. C. L. 4D Building Information Modeling and field operations: an exploratory study. In: ANNUAL CONFERENCE OF THE INTERNATIONAL GROUP FOR LEAN CONSTRUCTION, 21., Fortaleza, 2013. Proceedings [...] Fortaleza: IGLC, 2013.

HEIGERMOSERA, D. et al. BIM-based Last Planner System tool for improving construction project management. Automation in Construction, v. 104, p. 246-254, 2019.

HYATT, B. A. A case study in integrating Lean, Green, BIM into an undergraduate construction management scheduling course. In: ANNUAL INTERNATIONAL CONFERENCE OF CONSTRUCTION EDUCATION, 47., Fresno, 2011. Proceedings [...] Fresno: IGLC, 2011.

IBARRA, J. V. et al. Model for integrated production and quality control: implementation and testing using commercial software applications. In: ANNUAL CONFERENCE OF THE INTERNATIONAL GROUP FOR LEAN CONSTRUCTION, 24., Boston, 2016. Proceedings [...] Boston: IGLC, 2016.

JAMES, J.; IKUMA, L. H.; NAHMENS, I. The impact of Kaizen on safety in modular home manufacturing. The International Journal Advanced Manufacturing Technology, v. 70, p. 725-734, 2014.

JONGELING, R.; OLOFSSON, T. A method for planning of work-flow by combined use of location-based scheduling and 4D CAD. Automation in Construction, v. 16, p. 189-198, 2007.

KAMARDEEN, I. 8D BIM modelling tool for accident prevention through design Architectural Expression. In: ANNUAL CONFERENCE OF THE ARCOM, 26., Leeds, 2010. Proceedings [...] Leeds: IGLC, 2010.

KEMMER, S. et al. Implementing Last Planner in the context of social housing retrofit. In: ANNUAL CONFERENCE OF THE INTERNATIONAL GROUP FOR LEAN CONSTRUCTION, 24., Boston, 2016. Proceedings [...] Boston: IGLC, 2016.

KEMMER, S. et al. Using the line of balance for production system design. In: ANNUAL CONFERENCE OF THE INTERNATIONAL GROUP FOR LEAN CONSTRUCTION, 16., Manchester, 2008. Proceedings [...] Manchester: IGLC, 2008.

KEMMER, S.L. et al. The use of andon in high rise building. In: ANNUAL CONFERENCE OF THE INTERNATIONAL GROUP FOR LEAN CONSTRUCTION, 14., Santiago, 2006. Proceedings [...] Santiago: IGLC, 2006.

KHALFAN, M. A. A. et al. Application of Kanban in the UK construction industry by public sector clients. In: ANNUAL CONFERENCE OF THE INTERNATIONAL GROUP FOR LEAN CONSTRUCTION, 16. Manchester, 2008. Proceedings [...] Manchester: IGLC, 2008.

KITCHENHAM, B. et al. Systematic literature reviews in software engineering: a systematic literature review. Information and Software Technology, v. 51, n. 1, p. 7-15, 2009.

KOSEOGLU, O.; GUNES, E. T. N. Mobile BIM implementation and lean interaction on construction site. Engineering, Construction and Architectural Management, v. 25, n. 10, p. 1298-1321, 2018.

KOSEOGLU, O.; SAKIN, M.; ARAYICI, Y. Exploring the BIM and lean synergies in the Istanbul Grand Airport construction project. Engineering, Construction and Architectural Management, v. 25, n. 10, p. 1339-1354, 2018.

KOSKELA, L. An exploration towards a production theory and its application to construction. Espoo: Technical Research Centre of Finland, 2000.

LIN, E. T. A. et al. Framework for productivity and safety enhancement system using BIM in Singapore.

Engineering, Construction and Architectural Management, v. 24, n. 6, 2017. 
LIU, J.; SHI, G. Quality control of a complex lean construction project based on kanbim technology. EURASIA Journal of Mathematics, Science and Technology Education, v. 13, n. 8, p. 5905-5919, 2017.

LOVE, P. E. D. Influence of project type and procurement method on rework costs in building construction projects. Journal of Construction, Engineering and Management, v. 128, n. 1, p.18-29, 2002.

LU, Y. et al. Information and communication technology applications in architecture, engineering, and construction organizations: a 15-year review. Journal of Management in Engineering, v. 31, n. 8, 2015.

MAHALINGAM, A.; YADAV, K.; VARAPRASAD, J. Investigating the role of Lean practices in enabling BIM adoption: evidence from two Indian cases. Journal of Construction Engineering and Management, V. 141, n. 7, 2015.

MARIZ, R. N. et al. A review of the standardized work application in construction. In: ANNUAL CONFERENCE OF THE INTERNATIONAL GROUP FOR LEAN CONSTRUCTION, 20., San Diego, 2012. Proceedings [...] San Diego: IGLC, 2012.

MARIZ, R. N. et al. Production cells in construction: considering time, space and information linkages to seek broader implementations. Journal of Engineering, Project, and Production Management, v. 3, n. 1, p. 46-55, 2013.

MATTA, G. et al. Using BIM-based sheets as a visual management tool for on-site instructions: a case study. In: ANNUAL CONFERENCE OF THE INTERNATIONAL GROUP FOR LEAN CONSTRUCTION, 26., Chennai, 2018. Proceedings [...] Chennai: IGLC, 2018.

MCHUGH, K.; DAVE, B.; CRAIG, R. Integrated Lean and Bim processes for modularised construction - a case study. In: ANNUAL CONFERENCE OF THE INTERNATIONAL GROUP FOR LEAN CONSTRUCTION, 27., Dublin, 2019. Proceedings [...] Dublin: IGLC, 2019.

MCKINSEY. Reinventing construction: a route to higher productivity. New York: McKinsey Global Institute, 2017.

MIRANDA FILHO, A. N.; HEINECK, L. F. M.; COSTA, J. F. Lean as a counterbalance to complexity. In: ANNUAL CONFERENCE OF THE INTERNATIONAL GROUP FOR LEAN CONSTRUCTION, 24., Boston, 2016. Proceedings [...] Boston: IGLC, 2016.

MOGHADAM, M.; ALWISY, A.; AL-HUSSEIN, M. Integrated BIM/Lean base production line schedule model for modular construction manufacturing. In: ANNUAL CONSTRUCTION RESEARCH CONGRESS, Indiana, 2012, Proceedings [...] Indiana, ASCE, 2012.

MORANDI, M.; CAMARGO, L. Design science research. Porto Alegre: Bookman, 2015.

NATH, T. et al. Productivity improvement of precast shop drawings generation through BIM-based process re-engineering. Automation in Construction, v. 54, p. 54-68, 2015.

PENTTILÄ, H. Describing the changes in architectural information technology to understand design complexity and free-form architectural expression. ITcon, v. 11, p. 395-408, 2006.

PICCHI, F. A.; GRANJA, A. D. Construction sites: using lean principles to seek broader implementations. In: ANNUAL CONFERENCE OF THE INTERNATIONAL GROUP FOR LEAN CONSTRUCTION, 12. Helsinger, 2004. Proceedings [...] Helsinger: IGLC, 2004.

POIRER, E. A.; STAUB-FRENCH, S.; FORGUES, D. Measuring the impact of BIM on labor productivity in a small specialty contracting enterprise through action-research. Automation in Construction, v. 54, p. 54-68, 2015.

REYES, J. A. G. Lean and green: a systematic review of state of the art literature. Journal of Cleaner Production, v. 102, p. 18-29, 2015.

RILEY, D. The role of 4D modeling in trade sequencing and production planning. In: ISSA, R. R. A.; FLOOD, I.; O'BRIEN, W. J. 4D CAD and visualization in construction: developments and applications. Lisse; Abingon; Exton; Tokyo: A.A. Balkema Publishers, 2005.

ROSENBAUM, S.; TOLEDO, M.; GONZÁLEZ, V. Improving environmental and production performance in construction projects using value-stream mapping: case study. Journal of Construction Engineering and Management, v. 140, n. 2, 2014. 
SACKS, R. et al. Analysis framework for the interaction between Lean Construction and Building Information Modelling. In: ANNUAL CONFERENCE OF THE INTERNATIONAL GROUP FOR LEAN CONSTRUCTION, 17., Taipei, 2009. Proceedings [...] Taipei: IGLC, 2009.

SACKS, R. et al. BIM handbook: a guide to building information modeling for owners, managers, designers, engineers and contractors. $3^{\text {rd. }}$ ed. New York: Wiley, 2018.

SACKS, R. et al. Field tests of the Kanbim ${ }^{\mathrm{TM}}$ Lean Production Management System. In: ANNUAL CONFERENCE OF THE INTERNATIONAL GROUP FOR LEAN CONSTRUCTION, 19., Lima, 2011. Proceedings [...] Lima: IGLC, 2011.

SACKS, R. et al. Interaction of Lean and Building Information Modeling in construction. Journal of Construction Engineering and Management, v. 136, n. 9, p. 968-980, 2010.

SACKS, R. et al. KanBIM workflow management system: prototype implementation and field testing. Lean Construction Journal, p. 19-35, 2012.

SACKS, R.; RADOSAVLJEVIC, M.; BARAK, R. Requirements for building information modeling based lean production management systems for construction. Automation in Construction, v. 19, p. 641-655, 2010.

SACKS, R.; TRECKMANN, M.; ROZENFELD, O. Visualization of workflow to support Lean construction. Journal of Construction Engineering and Management, v. 135, n. 12, p. 1307-1315, 2009.

SAGGIN, A. D. B. et al. Standardized work: practical examples in a brazilian construction company. In: ANNUAL CONFERENCE OF THE INTERNATIONAL GROUP FOR LEAN CONSTRUCTION, 25., Heraklion, 2017. Proceedings [...] Heraklion: IGLC, 2017.

SANTOS, A. D.; MOSER, L.; TOOKEY, J. Applying the concept of mobile cell manufacturing on the drywall process. In: ANNUAL CONFERENCE OF THE INTERNATIONAL GROUP FOR LEAN CONSTRUCTION, 10., Gramado, 2002. Proceedings [...] Gramado: IGLC, 2002.

SANTOS, A. D.; POWELL, J. Potential of Poka-Yoke devices to reduce variability in construction. In: ANNUAL CONFERENCE OF THE INTERNATIONAL GROUP FOR LEAN CONSTRUCTION, 7. Berkeley, 1999. Proceedings [...] Berkeley: IGLC, 1999.

SANTOS, R.; COSTA, A. A.; GRILO, A. Bibliometric analysis and review of Building Information Modelling. Automation in Construction, v. 80, p. 118-136, 2017.

SCHEER, S. et al. On site BIM model use to integrate 4D/5D activities and construction works: a case study on a Brazilian low-income house enterprise. In: INTERNATIONAL CONFERENCE ON COMPUTING IN CIVIL AND BUILDING ENGINEERING, 15., Orlando, 2014. Proceedings [...] Orlando: 2014.

SEPPÄNEN, O.; MODRICH, R.; BALLARD, G. Integration of Last Planner System and location-based management system. In: ANNUAL CONFERENCE OF THE INTERNATIONAL GROUP FOR LEAN CONSTRUCTION, 23., Perth, 2015. Proceedings [...] Perth: IGLC, 2015.

SRIPRASERT, E.; DAWOOD, N. N. Multi-constraint information management and visualisation for collaborative planning and control in construction. Journal of Information Technology in Construction, v. 8, p. 341-366, 2003.

STAUB-FRENCH, S.; KHANZODE, A. 3D and 4D modeling for design and construction coordination: issues and lessons learned. Journal of information technology in construction (ITcon), v. 12, n. 26, p. 381-407, 2007.

STAUB-FRENCH, S.; RUSSELL, A.; TRAN, N. Linear scheduling and 4D visualization. Journal of Computing in Civil Engineering, v. 22, n. 3, p. 192-205, 2008.

TEICHOLZ, P. BIM for facilities management. New Jersey: Hoboken, 2013.

TEZEL, A.; AZIZ, Z. From conventional to IT-based visual management: a conceptual discussion for lean construction. Journal of Information Technology in Construction, v. 22, p. 220-246, 2017 a.

TEZEL, A.; AZIZ, Z. Visual management in highways construction and maintenance in England. Engineering, Construction and Architectural Management, v. 24, n. 3, p. 486-513, $2017 \mathrm{~b}$.

TILLMANN, P.; SARGENT, Z. Last Planner \& Bim Integration: lessons from a continuous improvement effort. In: ANNUAL CONFERENCE OF THE INTERNATIONAL GROUP FOR LEAN CONSTRUCTION, 24., Boston, 2016. Proceedings [...] Boston: IGLC, 2016. 
TOLEDO, M.; OLIVARES, K.; GONZÁLEZ, V. Exploration of a Lean-Bim planning framework: a Last Planner System and Bim-based case study. In: ANNUAL CONFERENCE OF THE INTERNATIONAL GROUP FOR LEAN CONSTRUCTION, 24., Boston, 2016. Proceedings [...] Boston: IGLC, 2016.

TOMMELEIN, I. D. Poka Yoke or quality by Mistake proofing design and construction systems. In: ANNUAL CONFERENCE OF THE INTERNATIONAL GROUP FOR LEAN CONSTRUCTION, 16. Manchester, 2008. Proceedings [...] Manchester: IGLC, 2008.

VARGAS, F. B.; BATAGLIN, F. S.; FORMOSO, C. T. Guidelines to develop a BIM model focused on construction planning and control. In: ANNUAL CONFERENCE OF THE INTERNATIONAL GROUP FOR LEAN CONSTRUCTION, 26., Chennai, 2018. Proceedings [...] Chennai: IGLC, 2018.

VIANA D. D.; FORMOSO, C. T.; KALSAAS, B. T. Waste in construction: a systematic literature review on empirical studies. In: ANNUAL CONFERENCE OF THE INTERNATIONAL GROUP FOR LEAN CONSTRUCTION, 20., San Diego, 2012. Proceedings [...] San Diego: IGLC, 2012.

VON HEYL, J.; TEIZER, J. Lean Production controlling and progress tracking using digital methods. In: ANNUAL CONFERENCE OF THE INTERNATIONAL GROUP FOR LEAN CONSTRUCTION, 25., Heraklion, 2017. Proceedings [...] Heraklion: IGLC, 2017.

WANG, J. et al. Developing and evaluating a framework of total constraint management for improving workflow in liquefied natural gas construction. Construction, Management and Economics, v. 34, n 12, p. 859-874, 2016.

WARD, S. A.; MCELWEE, W. Application of the principle of batch size reduction in construction. In: ANNUAL CONFERENCE OF THE INTERNATIONAL GROUP FOR LEAN CONSTRUCTION, 15. Michigan, 2007. Proceedings [...] Michigan: IGLC, 2007.

WEN, Y. Research on cost control of construction project based on the theory of lean construction and BIM: case study. The Open Construction \& Building Technology Journal, v. 1, n 8, p. 382-388, 2014.

WOMACK, J. P.; JONES, D. T. Lean Thinking: banish waste and create wealth in your corporation. New York: Simon \& Schuster, 1996.

YU, H. et al. Development of Lean model for house construction using value stream mapping. Journal of Construction, Engineering and Management, v. 135, n. 8, p. 782-790, 2009.

ZENG, N.; KÖNIG, M.; TEIZER, J. Off-site guarding: look-ahead supply scheduling for risk indication with BIM. In: ANNUAL CONFERENCE OF THE INTERNATIONAL GROUP FOR LEAN CONSTRUCTION, 25., Heraklion, 2017. Proceedings [...] Heraklion: IGLC, 2017.

ZHANG, X. et al. Using Building Information Modelling to achieve Lean principles by improving efficiency of work teams. International Journal of Construction Management, v. 18, n. 4, p. 293-300, 2018.

\section{Acknowledgements}

The authors would like to thank CAPES for funding part of the study. 


\section{Renato Nunes Mariz}

Faculdade de Engenharia Civil, Arquitetura e Urbanismo | Universidade Estadual de Campinas | Rua Saturnino de Brito, 224 | Campinas SP - Brasil | CEP 13083-889 | Tel.: (19) 3521-2307 | E-mail: renatonunesmariz@hotmail.com

\section{Flavio Augusto Picchi}

Faculdade de Engenharia Civil, Arquitetura e Urbanismo | Universidade Estadual de Campinas | E-mail: fpicchi@unicamp.br

\section{Ambiente Construído}

Revista da Associação Nacional de Tecnologia do Ambiente Construído

Av. Osvaldo Aranha, $99-3^{\circ}$ andar, Centro

Porto Alegre - RS - Brasil

$$
\text { CEP } 90035-190
$$

Telefone: +55 (51) 3308-4084

www.seer.ufrgs.br/ambienteconstruido

www.scielo.br/ac

E-mail: ambienteconstruido@ufrgs.br

(c) (i) This is an open-access article distributed under the terms of the Creative Commons Attribution License.

328 Mariz, R. N.; Picchi, F. A. 